\title{
Islam and Good Governance: A Political Economy Perspective
}

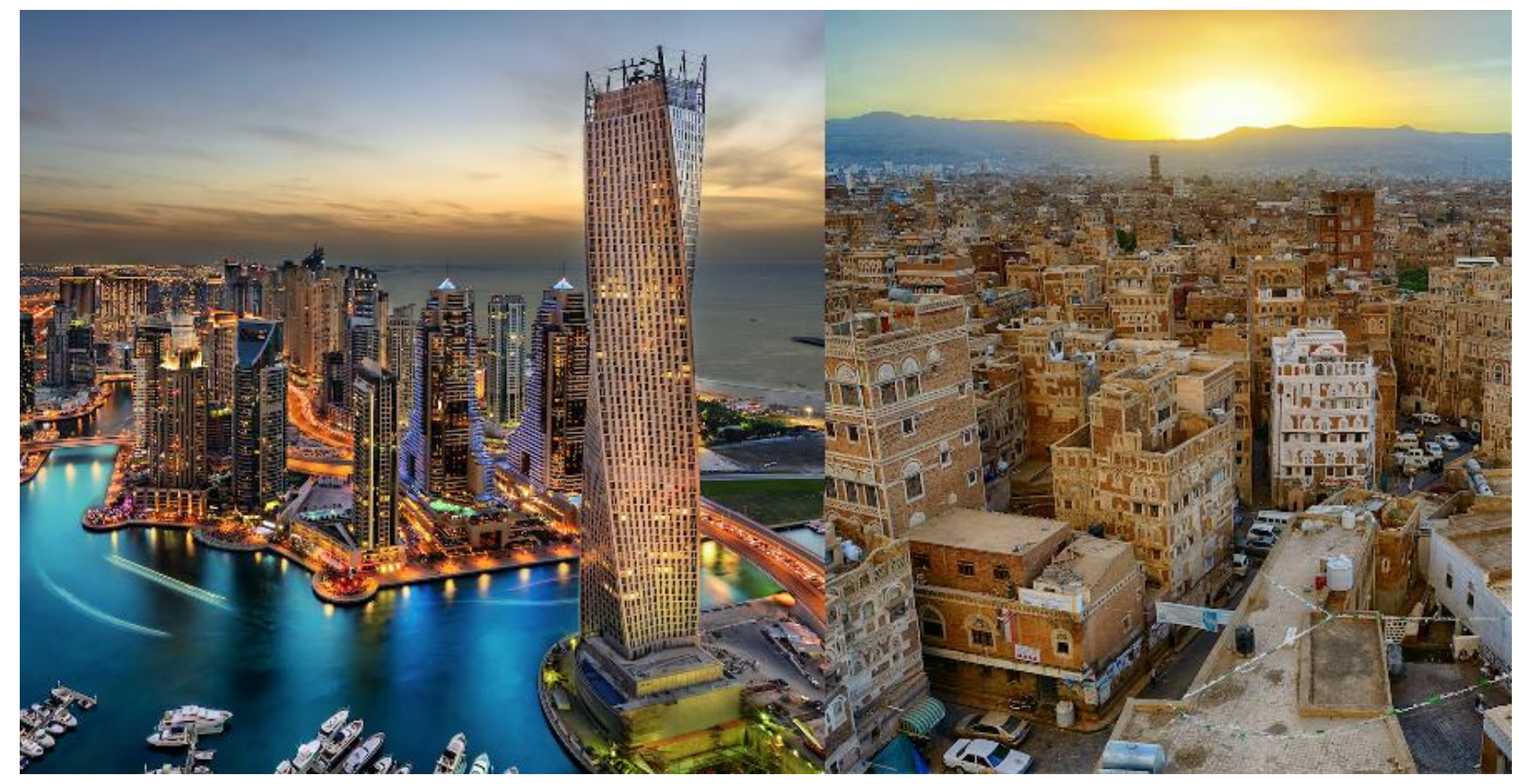

\section{Amir Ullah Khan}

Centre for Development Policy and Practice

Hyderabad, India

Symposium on Islam and Good Governance

Muqtedar Khan (Ed.)

International Institute of Islamic Thought | October 2020

DOI: $10.47816 / 01.004 .20$ 
It is readily apparent to everyone that there are multiple and serious concerns that face Muslim societies today. Terrorism, civil strife, poverty, illiteracy, factionalism, gender injustices and poor healthcare are just a few of the challenges to governance across the Muslim world. These are core issues for governance and public administration in any form of government. However, before we can engage with good governance within the context of Islam, we need to be clear what mean by good governance itself. A simple definition of good governance is that of an institutionalised competency of administration and institution leading to efficient resource allocation and management ${ }^{1}$. Another way of looking at it is as a system which is defined by the existence of efficient and accountable institutions ${ }^{2}$. Civil society now tends to look at good governance by way of impact measurement and how a certain set of processes result in a set of measurable and desirable outcomes.

Given these various contours of what is seen as good governance, there is a need to look for the Islamic definition of the same. How does Islam view the issue of governance and administration? It is in defining good governance from an Islamic perspective that the book Islam and Good Governance excels3. Khan, in the very beginning underlines his objective in writing this text. The purpose is to reinforce the foundations of love, compassion and mercy and to discourage the notions of divine justice that then descend into harsh, intolerant and distasteful institutions that almost always tend to negate the very purpose of a system based on the Quran and the Sunnah. The book is clear in its purpose, that of advancing a form of governance where love prevails over law, process over structure and where virtue rules over identity and ethics over politics.

But when we approach the matter from a political economy perspective, we are confronted with a very different set of challenges - cross border issues, trade wars, falling interest rates, an inexplicable rise in stock values, galloping inequalities and a stagnation in GDP growth that is fuelling unemployment and therefore a resentment among social groups. The twenty first century began with the internet bust, the euro crisis, the steep fall in oil prices and now the COVID 19 pandemic. Given these tumultuous 
development and their occurrence, at a frenetic pace. The Islamic world unfortunately has been caught in the vortex and is unfairly seen by many as the eye of the storm for many of the tragedies the world faces. In Muslim countries, already helpless populations face these staggering crises rather breathlessly. The political administrations are repeatedly caught napping and are grossly unprepared, to put it mildly. Therefore a fresh look at what governance means and how it needs to be improved within the Islamic framework is essential, and Khan's Islam and Good Governance, is a worthy contribution to this cause.

An issue that is now challenging world peace and cooperation is the growing income inequality, in every country. While global inequality has historically been a product of differences between Europe and Asian income levels, it is the spectacular increase in intra-Asian inequality that has grown since the 1950s4. This impacts the Muslim world both from the outside and the inside. While inequality within the Islamic world creates pressures on the economy, it also drives large scale migration from East and South Asia to West Asia and from the Middle East to the Western world. An political economic analysis of the violence and strife in the Middle East is missing. There is a need to explore how stark economic inequality between very rich countries like Kuwait and Saudi Arabia sharing borders with relatively poor nations could be triggering or at least impacting the conflicts in the region. Europe blames its own civil strife on Muslim migrants while Muslim societies in various countries find the rich getting richer by the day. Khan goes beyond the mechanism of Zakat to addresses this issue. 5 It is Khan's vision that Ihsan as the defining feature of Islamic society, that emphasises love and self-effacement (Fanaa), cannot tolerate such huge differences in wealth, leading to acute deprivation on one hand and colossal incomes on the other. Khan underlines the importance of the Muhsin in the development of any society. Muhsins build a society's character and use that to develop fair and equitable policy. It is this character and its absence that could explain much of the economic woes seen across the West Asian and North African regions

The modern world is facing challenges from a new set of perplexing and paradoxical views that emerge from the confluence of globalisation and nationalism across 
the entire planet. The heydays of globalisation that we saw in the twentieth century was built on the colonial structure of the eighteenth and nineteenth centuries. The Islamic world faced these international challenges rather helplessly over the last three hundred years and remained for the most part, a passive bystander. National boundaries were redrawn and international treaties and multilateral institutions came up almost always without any significant input from the Muslim world. In the era that began after the cold war, in the age of neoliberalism of market economies and global trade, Muslim nations watched from the galleries as governance systems changed and transformed themselves everywhere. Today as the world turns anti-global, once again the institutions that govern Muslim nations look on with no local or global contribution.

There has been very little scholarly work on markets and Islamic ethical governance. Choudhary and Malik have looked 6 at how welfare and development works in an Islamic society that is built on Quranic principles. Khan's book does not tackle economic issues directly and in its emphasis on how a society needs to be governed talks of the need for freedom and virtue to guide growth and equitable development. The book talks of how justice ought to be looked at in the framework of good governance and the importance of looking at the system of law and justice systemically. Justice, Khan argues, must be seen outside the confines of law and legal procedure. Such shackling of economic systems, under rigid and even arcane legal principles, leads to the kind of inequality we see in the world today. This is in totally opposition to the goals of an Islamic society that is based on freedom and equality.

The discussion on secularism is a major topic and Khan's book takes to sublime levels. This is the section where the book discusses what constitutes the secular and why the Islamic world has abandoned modern secular governance. There is a tendency to see the secular as unIslamic or to see secular approaches as the reason for the appalling conditions of the poor and the marginalised. The secular model of governance, according to Khan suffered not so much because of structural and definitional issues but because of poor governance, high levels of corruption, poorly run economic institutions, large scale unemployment and an absence of 
freedom for the individual. These are antithetical to any economic system anywhere and Muslim countries were unable to tackle these basic issues and therefore hardened positions amongst some intellectuals against the secular idea itself.

What the book and its discussion therefore highlight is the need to look at how Islamic principles of Ihsan allow institutions to be developed that would pave the way for reaching the Millennium Development Goals or now the Sustainable Development Goals. Both these frameworks have been used to measure the world's movement towards socio economic equality and justice. Muslim countries almost always are found lacking in the path towards these targets defined under the UN system. Very little work has been done on this aspect, except in Malaysia and in Indonesia. 7 The Islamic Development bank (IDB) also refers to these frameworks in some of its projects while helping Muslim countries reach those goals. ${ }^{8}$ Khan's book will do well with a sequel that focuses on how to use the same concepts that he delineates with such lucidity in fostering justice and freedom in the Islamic world. The book is excellent in identifying "what to" but not very forthcoming on "how to". Even though Khan marshals resources from several disciplines, theology, philosophy, mysticism, history, law, and jurisprudence, Islam and Good Governance is a project in political philosophy and not political economy.

The Islamic world's tryst with the rapidly declining standards of economic governance throughout the world will need to be re-examined through the same lens of Ihsan and good governance that Khan prescribes for political aspects. The rise of majoritarianism and of anti-migrant policies across the world emerge from narrow definitions of citizenship and nationalism. Islam and its mature understanding of the westernised world would enable a system to emerge that would negate much of the negativity that has emerged in a world that is now showing its dissent against globalisation. Roy ${ }^{9}$, for example shows how the moderate and the western Muslim is reasserting Islamic principles to understand and tackle emerging conflicts in a post globalisation world. Sule et al ${ }^{10}$ argue that globalisation emphasised the decline of cultural practises which Islamic nations resist and continue to fight against. In the absence of an 
Ihsan framework, this resistance could often turn violent and ungainly.

It is therefore imperative for the Muslim world to look afresh at the new realities of a word that is caught in geopolitical strife driven by harsh economic conflicts that emerge in competitive trade environments. The World Trade Organisation struggles as it tries to bring members together, who are forever looking at self-interest driven by political frameworks that have local constituencies that look suspiciously at various service sectors opening up to foreign workers. A technology driven interface brings strange parts of the world's supply chains together disrupting homegrown and indigenous manufacturing hubs. Commodity exports that were the mainstay of most Islamic nations now are threatened by new and emerging issue of climate change, greenhouse impacts and environmental degradation. All these threats must be evaluated afresh and Khan's emphasis on Ihsan as the cornerstone of policy brings back the foundations that Islamic governance believed in and thrived on. The principles of Ihsan that Khan's books explains need to be understood and applied to enable just and fair political outcomes that would then lead to greater economic growth that is sustainable and inclusive.

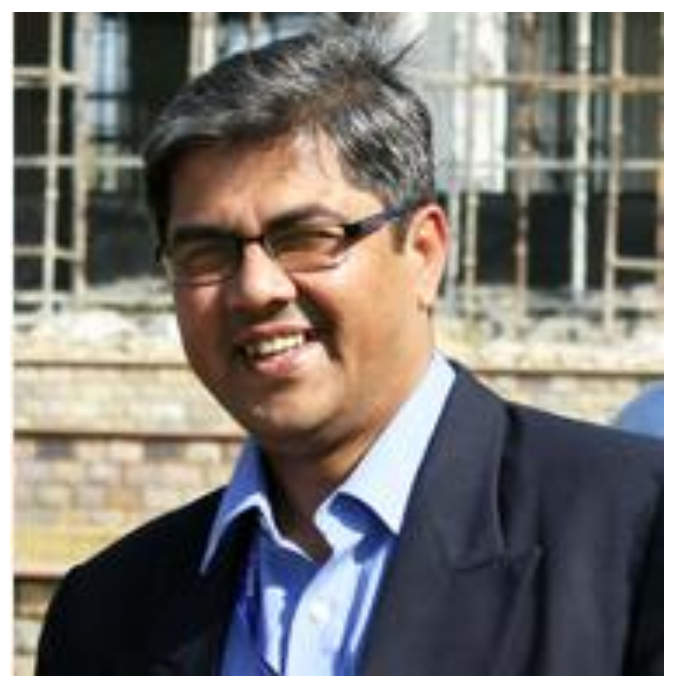

Dr. Amir Ullah Khan has a PhD in

Economics and Business Studies from the Jamia Millia University and is a Professor of Economic Policy at the MCRHRDI (Marri Chenna Reddy Human Resource Development Institute) of the Government of Telangana in Hyderabad, India. A former civil servant, Amir has worked at Project LARGE (Legal Adjustments and Reforms for Globalising the Economy) of the Ministry of Finance, Government of India and the UNDP. He then worked with Encyclopaedia Britannica as executive director and editor after which he was Senior Fellow and Director at The India Development Foundation. He has been head of research and strategy at the Bill and Melinda Gates Foundation. 
Dr. Khan served as a member of the Board of Governors at the Presidency University, Bangalore. He is also a member in the Telangana

Government's Commission of Inquiry on Socio-economic conditions of Muslims in the state. He has been
Adjunct Professor of Business and Law at the Edith Cowan University. He teaches at the Indian School of Business and the NALSAR University of Law in Hyderabad.

\title{
END NOTES
}

\begin{abstract}
${ }^{1}$ Kraipornsak, P. (2018). Good governance and economic growth: An investigation of Thailand and selected Asian countries. Eurasian Journal of Economics and Finance, 6(1), 93-106.

${ }^{2}$ Davis, T. J. (2017). Good governance as a foundation for sustainable human development in sub-Saharan Africa. Third World Quarterly, 38(3), 636-654.
\end{abstract}

3 Khan, M. a> Muqtedar (2019). Islam and Good Governance: A Political Philosophy of Ihsan. Palgrave-Macmillan.

4 Modalsli, J. (2017). Decomposing global inequality. Review of Income and Wealth, 63(3), 445-463.

5 Bashir, A. H. M. (2018). Reducing poverty and income inequalities: Current approaches and Islamic perspective. Journal of King Abdulaziz University: Islamic Economics, 31(1).

${ }^{6}$ Choudhury, M. A., \& Malik, U. A. (2016). The foundations of Islamic political economy. Springer.

7 Suprayitno, E. (2019, October). Zakat and SDGs: The Impact of Zakat on Economic Growth, Consumption and Investment in Malaysia. In 2018 International 
Conference on Islamic Economics and Business (ICONIES 2018). Atlantis Press.

8 Nafar, N. (2018). Affordable Housing Development and SDGs The Role of Islamic Finance.

9 Roy, O. (2017). Globalized Islam: the search for a new Ummah. Islamology, 7(1), 11-40. Roy, O. (2017). Globalized Islam: the search for a new Ummah. Islamology, $7(1), 11-40$.

${ }^{10}$ Sule, B., Yahaya, M. A., \& Ating, R. (2018). Globalisation and the Muslim Ummah: Issues, Challenges, and the Ways Out. IIUM Journal of Religion and Civilisational Studies, 1(1), 7-29. 